\title{
The seed bank of subtropical grasslands with contrasting land-use history in southern Brazil
}

\author{
Mariana de Souza Vieira ${ }^{1 *}$, Camila Leal Bonilha ${ }^{1}$, Ilsi Iob Boldrini1 ${ }^{1,2}$ and Gerhard Ernst Overbeck ${ }^{1,2}$
}

Received: February 3, 2015. Accepted: August 10, 2015

\begin{abstract}
The expansion of land use for agriculture is among the main reasons for the reduction of natural grasslands around the world, and little is known about the recovery potential of original native grassland vegetation from seed banks. The aim of this study was to assess the seed bank potential of grassland areas with or without history of cultivation in southern Brazil. Specifically, we aimed at evaluating if agricultural use allowed for the persistence of species typical of natural grasslands in soil seed banks. We analyzed seed banks in two areas with a history of cultivation and in two natural grasslands. Samples were collected in spring and autumn in order to assess transient and persistent components, and were characterized by density, richness, presence of exotic species and relationship between seed bank and established vegetation. Both richness and density were high; we found a total of 114 species and a mean density of 61,796 seedlings $/ \mathrm{m}^{2}$ for all four areas in the spring sampling. In the natural grasslands, the dominant species of established vegetation were mostly absent from the soil seed bank. Our study indicates that the seed bank is of little relevance for the recovery of typical grassland vegetation after disturbance.
\end{abstract}

Keywords: Campos Sulinos, disturbance, land use, persistent seed bank, recovery, transient seed bank

\section{Introduction}

With rising impacts of land use changes on biodiversity, understanding recovery processes of vegetation after severe disturbance has become increasingly important. Land use changes have been considered to be the most important factor affecting biodiversity in this century, and grassland ecosystems are among the most impacted by land conversion (Sala et al. 2000). Land use also affects a wide range of ecosystem services and functions (White et al. 2000; Bullock et al.2011), many of which are closely related to biodiversity (Millennium Ecosystem Assessment 2005; Perrings et al. 2010). A better understanding of the regeneration potential of natural vegetation after intensive land use becomes important as a basis for conservation or restoration policy and for a better integration of these with agricultural policy (Mattison \& Norris 2005).

The soil seed bank represents the main regenerative potential of vegetation in areas that have suffered severe disturbance, and at the same time can be considered the memory of past environmental conditions and vegetation established previously (Bakker et al. 1996; Thompson 2000). Data about the similarity or dissimilarity between aboveground vegetation and the seed bank can provide information about the potential of recovery of vegetation after disturbance, successional pathways after abandonment and susceptibility to biological invasions (Loydi et al. 2012). Additionally, seed bank data may help to evaluate whether restoration of degraded ecosystems requires the addition of seeds of target species with low seed numbers (e.g. Kiehl et al. 2010).

Around the world, and especially in the tropics and subtropics, grasslands are suffering from conversion to other land uses and often are not the focus of conservation action (Bond \& Parr 2010; Veldman et al. 2015). The Brazilian Pampa biome, the northern part of the large grassland region extending around the Rio de la Plata (Soriano 1992) is known for its high diversity and the forage potential of its grasslands (Overbeck et al. 2007; Boldrini 2009; Nabinger et al. 2009). However, despite the high potential for traditional extensive livestock grazing, land use change strongly affects the region. By 2002, about $50 \%$ of original grassland area had been converted into agricultural (crops) and silvicultural areas (Cordeiro \& Hasenack 2009). The coastal region has been particularly affected by land use change, with only about $15 \%$ of grasslands still considered well conserved (equivalent to approx. $2690 \mathrm{~km}^{2}$; Cordeiro \& Hasenack 2009). In southern Brazil, the production of

\footnotetext{
${ }^{1}$ Programa de Pós-Graduação em Botânica, Instituto de Biociências, Universidade Federal do Rio Grande do Sul, 91501-970, Porto Alegre, RS, Brazil

${ }^{2}$ Departamento de Botânica, Instituto de Biociências, Universidade Federal do Rio Grande do Sul, 91501-970, Porto Alegre, RS, Brazil

"Corresponding author: marianasvbio@gmail.com
} 
soy and rice is one of the most important drivers for the conversion of natural areas. Soybeans are the fastest growing crop in Latin America (Grau \& Aide 2008).

Impacts of these changes on biodiversity and degradation effects and processes have received little research attention, which is a problem for grassland restoration (Cramer et al. 2008; Zaloumis \& Bond 2011). The principal regenerative potential in areas that have suffered severe disturbances, i.e. where no established plants can be found anymore, comes from the soil seed bank which at the same time can be considered the memory of the vegetation established previously (Bakker et al. 1996; Thompson 2000). According to Bakker et al. (1996), the seed bank can be classified into the transient seed bank (composed of seeds that remain in the soil for less than year after their dispersion) and the persistent seed bank (formed by seeds that remain viable for more than a year after their dispersion). Obviously, it is mainly the persistent fraction of the seed bank that can determine the potential for reestablishment of original species and thus the resilience of degraded vegetation (Scott \& Morgan 2012), e.g. in grasslands that had been suffered severe disturbances by cultivation or other temporary changes in land use.

To date, only very few published studies of the seed bank in subtropical grasslands in southern Brazil exist, and even less so studies that include the seed bank of areas that had suffered such changes in the past and then were used as grassland again (Maia et al. 2003; Favreto \& Medeiros 2006). According to the review by Hopfensperger (2007), a high similarity of established vegetation and the seedbank is a general feature of grassland ecosystems that have not been subject to disturbances for longer periods, even though there are exceptions (e.g. Hopfensperger 2007) and generalizations thus may be difficult. The objective of the present study, conducted in the coastal region of southern Brazil, was to assess the seed bank of grassland areas with (1) a history of agricultural cultivation (rice and soybean production in rotational use with grazing) and (2) a history of cattle grazing only. We considered seed bank species richness, density, presence of exotic species, percentage of perennial and non-perennial species and similarity between seed bank and established vegetation. Additionally, we wished to assess, in terms of number and composition, the importance of the transient seed bank (composed of seeds that remain in the soil for less than year after their dispersion) and the persistent seed bank (formed by seeds that remain viable for more than a year after their dispersion) components (Bakker et al. 1996). With this, we aimed to evaluate if the agricultural management of the areas allows for persistence of species typical for natural grassland in the soil seed bank, as well as to improve knowledge of the role of the seed bank for natural grasslands in the Subtropics and to verify if it corresponds to the general findings in the literature (Hopfensperger 2007).

\section{Materials and Methods}

\section{Study area}

The study was conducted on the Cordilheira farm (1,039 ha) in the coastal plain in the extreme south of Brazil, in the municipality of São Lourenço do Sul (31 $1^{\circ} 18^{\prime} \mathrm{S}$ and $51^{\circ} 58^{\prime}$ $\mathrm{W}$, average altitude $7 \mathrm{~m}$ ). Climate is humid subtropical (Cfa) with a mean annual rainfall of $1265 \mathrm{~mm}$ and mean annual temperature of $17.9^{\circ} \mathrm{C}$ (http://www.cpact.embrapa. br/agromet/estacao/normais.html, data for 1971-2000). Soils in the region are Alfisols albiqualf (Planosolos haplicos eutróficos according to the Brazilian classification; Streck et al. 2008) and Entisols quartzipsamments (Neossolos quartzarêncisos), with low water retention and low natural fertility (Boldrini 1997).

Land use in the Cordilheira farm is typical for the region. Traditional use is livestock grazing, but the past decades, substantial areas have been transformed into rice fields. More recently, soybean is grown in the region. It is common practice to alternate cropping and grazing. Between soybean crops, areas are usually grazed for less than a year, whereas areas may be grazed for several years between rice crops. Usually the cool-season grass Lolium multiflorum L. (ryegrass) is seeded after soybean cultivation, in order to rapidly establish a vegetation cover that can be grazed. Four different areas were selected for our study, all of them homogeneous with regard to topography:

- grassland/rice: Area ( $30 \mathrm{ha}$ ) that had been used for rice production for approximately fifty years, with periods (usually one to three years) of grazing between rice cycles. For the six years prior to the study the area was only grazed, without any overseeding after the last rice cycle.

- grassland/soybean: Grassland (24 ha) with overseeding of Lolium multiflorum in a rotational system with soybean, seeded 6 month before our first sampling. This management (soybean seeded in spring, ryegrass in autumn) had been adopted in 2009, i.e. two years before the start of our study. From October 2011 to April 2012, the established vegetation consisted exclusively of soybean.

- grassland: Native grassland (9 ha) used for livestock grazing, never cultivated or seeded with exotics species.

- humid grassland: Native grassland (8 ha) used for livestock grazing, without history of other types of use, never cultivated or seeded with exotics species. The area is poorly drained, with slightly wetter conditions than the other area.

\section{Vegetation description}

The floristic composition of the established vegetation was recorded monthly by three people walking the entire study areas, recording all species. This survey was conducted for the period of one year, from July 2011 to July 2012. Species that could not be identified in situ were collected for later identification at the Laboratory of Grass- 
land Vegetation Studies, Department of Botany, Institute of Biosciences (UFRGS). A quantitative vegetation assessment was conducted in September 2011. Twenty plots of $0.5 \mathrm{~m}^{2}$ were randomly allocated in each area. In each plot, the cover of all plant species and the percentage of bare ground were recorded using the scale proposed by Londo (1976).

\section{Sampling of the soil seed bank}

Soil samples for the seed bank study were collected in two seasons, spring (September) 2011 and autumn (April) 2012. In spring, i.e. before the period of seed rain for most species (spring to late summer), we expected that only the persistent part of the soil seed bank would be sampled. In contrast, the the transient component should be present in the autumn sample, after the main period for seed rain (Thompson \& Grime 1979; Ortega et al. 1997). The samples were collected with an auger $(5 \mathrm{~cm}$ in diameter and $10 \mathrm{~cm}$ deep). In each area, soil was collected at ten points randomly distributed in the area, with four samples per point. Points were marked by GPS at the first sampling date, and sampling was conducted at approximately the same point at the second date. The soil samples were divided into two depths $(0-5 \mathrm{~cm}$ and $5-10 \mathrm{~cm})$. This was done in order to evaluate if land use practices were associated to different patterns of distribution in terms of soil depth. The four samples from each depth were mixed for one combined sample, resulting in two combined samples per point, representing the two depth categories at each sampling data. Subsequently, the soil samples were dried for seven days and then sifted, using a $2 \mathrm{~mm}$ mesh to promote the unpacking of soil (Garcia 2009). Roots and plant fragments were removed in order to avoid vegetative propagation. Any large seeds that were sieved out were returned to the sample.

\section{Seed bank assessment}

Composition and seed density of the germinable seed bank were estimated using the method of seedling emergence (Thompson \& Grime 1979). Since emerging plants are counted, the method indicates the number of viable seeds, while excluding nonviable seeds (Poiani \& Johnson 1988). For each sampled point, $50 \%$ of the total volume collected in the field was mixed with the same amount of vermiculite (Favreto \& Medeiros 2006) and distributed into aluminum trays of $700 \mathrm{ml}$ volume, forming a soil layer of about $2 \mathrm{~cm}$ (sufficient to maintain moisture in the sample). The samples were kept in a greenhouse at the Department of Forage Plants and Agrometeorology at the Faculty of Agronomy of UFRGS, under a natural temperature regime. Trays with sterile soil were distributed randomly between samples as controls to detect possible contamination by seed rain. The samples were watered every one or two days, as required. We identified emerging seedlings as soon as possible. For species that could not be identified right away, we transplanted at least one specimen into a larger pot where it remained until the reproductive stage for later identification. Seedling emergence was monitored weekly for a period of one year for each of the two sampling dates. Due to continuous germination of seeds in trays, we did not include break periods and soil revolving. Most taxa were identified to species level.

\section{Data Analysis}

Density data of sampling units was transformed into seeds per square meter in order to facilitate interpretation (based on the volume and corresponding area of soil sampled in the field and effectively used in the trays). Seed density and number of species were calculated for each sample and area. Species were classified according to life cycle (perennial and non-perennial), biological type (subshrubs, sedges and rushes, herbs, and grasses), geographical origin (native or exotic) and seed bank type. For the latter, we considered the two categories transient (when the species was found only in the sample collected in autumn) and persistent (when they species was found in samples from spring or from both seasons; see Bakker et al. 1996). We considered this classification more useful for our study than the alternative classification proposed by Bakker (1989), which relies on the abundance of seeds present in the upper and lower layers of the soil, as agricultural practices in the two areas with intensive use may have affected vertical distribution of seeds in the soil.

A Principal Coordinate Analysis was conducted, using the software MULTIV (Pillar 2006) based on seed bank abundance data (using chord distance as resemblance measure). For comparison of relative importance of upper and lower layer of soil with established vegetation we used data from the quantitative assessment. Sørensen's coefficient of similarity was used to evaluate the similarity between the soil seed bank and the aboveground vegetation for each area. For this, we used both floristic and quantitative vegetation data.

\section{Results}

\section{Seed bank density, richness and composition}

A total of 114 taxa were identified in the seed bank, 81 of them present in the spring sample and 95 in the autumn sample. A total of 9,707 germinated seeds (mean of 61,796 seedlings $/ \mathrm{m}^{2}$ for all four areas) were counted in the seed bank collected in the spring season, $77 \%$ of which were present in the upper layer. In the autumn seed bank, 4,234 germinating seeds (mean of $26,954 . \mathrm{m}^{-2}$ ) were recorded (64\% in the upper layer). From the 114 species recorded, $86 \%$ were natives and $14 \%$ exotics. $74 \%$ of species were classified as persistent and $26 \%$ as transient, based on their appearance in only the autumn or both the spring and autumn seed bank. Overall richness was highest for the autumn data, for all areas (Fig. 1). Richness was higher in both areas with 

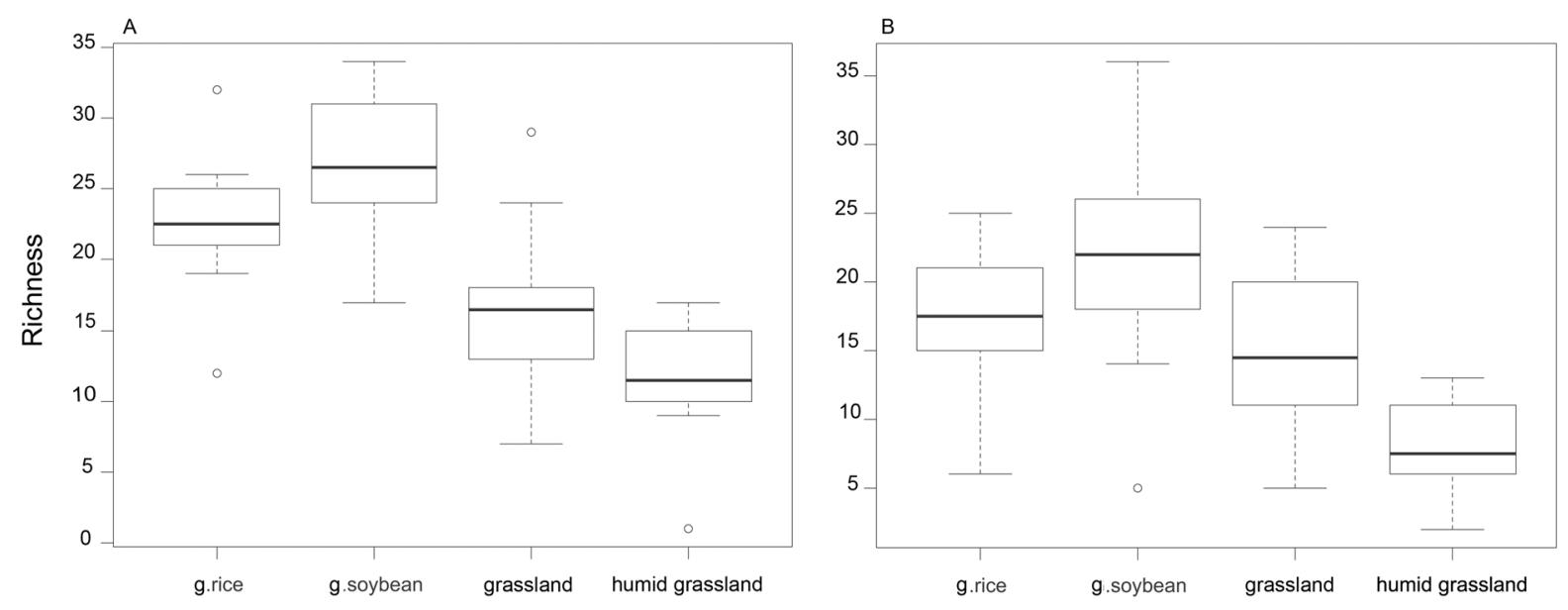

Figure 1. Species richness per area in in São Lourenço, RS, Brazil: spring seed bank (A) and autumn seed bank (B). Areas: grassland/rice - g.rice; grassland/soybean - g.soybean; grassland and humid grassland - h.grassland.

present and past cultivation when compared to areas used for traditional extensive livestock grazing. Of all species, between 11 and 14\% were found only in the lower layer in the spring sampling, and 17 to $28 \%$ in the autumn sampling (Tab. 1). Approximately $20 \%$ of all species appeared with three seedlings or less in the total of samples, demonstrating the necessity of a large sampling effort for evaluating the composition of the seed bank.

In spring, almost 59,639 seeds $/ \mathrm{m}^{2}$ were found in the upper layer of the native grassland and more than 71,352 seeds $/ \mathrm{m}^{2}$ in the native humid grassland. 31,991 seeds $/ \mathrm{m}^{2}$ were sampled in the grassland/rice and $29,412 \mathrm{seeds} / \mathrm{m}^{2}$ in the grassland/soybean area (Fig. 2). In all areas, the density values of the lower layer were considerably lower than those of the upper layer, with a median below 20,000 seedlings $\mathrm{m}^{2}$ in all areas. Overall, the native grassland areas showed discrepancy regarding number of seeds per sample, as evidenced in Fig. 2.

The seed bank density of both layers was lower in autumn than in spring, in all areas. We found 19,481 seeds $/ \mathrm{m}^{2}$ in the grassland/rice area, 29,386 seeds $/ \mathrm{m}^{2}$ in the grassland/ soybean area and 18,513 seeds $/ \mathrm{m}^{2}$ and 2,699 seeds $/ \mathrm{m}^{2}$ in grassland and humid grassland, respectively (Fig. 2D). In the lower layer of the soil, the greatest density of seeds $\mathrm{m}^{-2}$ was found for the grassland/soybean area (Fig. 2E).

For the spring seed bank, dominance by only one species was striking in the two grassland areas: Rhynchospora britonii accounted for $77.9 \%$ and $88.5 \%$ of seedlings sampled in the grassland and the humid grassland, respectively. In contrast, in the two areas with agricultural use, Anagallis minima, the most abundant species, accounted for $22.4 \%$ (grassland/rice) and 23.9\% (grassland/soybean) of seedlings. In autumn, the most abundant species were different between areas. Crassula peduncularis represented $32.3 \%$ of individuals in the grassland/rice area, and Anagallis minima to $35.9 \%$ in the grassland/soybean area. The grassland
Table 1. Percentage of species found in the seed bank upper layer $(0-5 \mathrm{~cm})$, lower layer $(5-10 \mathrm{~cm})$, and both layers, in São Lourenço do Sul, RS, Brazil.

\begin{tabular}{lcccc}
\hline & $\begin{array}{c}\text { grassland/ } \\
\text { rice }\end{array}$ & $\begin{array}{c}\text { grassland/ } \\
\text { soybean }\end{array}$ & $\begin{array}{c}\text { grazed } \\
\text { grassland }\end{array}$ & $\begin{array}{c}\text { humid } \\
\text { grassland }\end{array}$ \\
\hline Spring sampling & & & & \\
Only in upper layer & $38 \%$ & $41 \%$ & $39 \%$ & $60 \%$ \\
Only in lower layer & $12 \%$ & $11 \%$ & $11 \%$ & $14 \%$ \\
In both layers & $50 \%$ & $48 \%$ & $50 \%$ & $26 \%$ \\
Autumn sampling & & & & \\
Only in upper layer & $22 \%$ & $33 \%$ & $43 \%$ & $40 \%$ \\
Only in lower layer & $28 \%$ & $17 \%$ & $18 \%$ & $23 \%$ \\
In both layers & $50 \%$ & $50 \%$ & $38 \%$ & $38 \%$ \\
\hline
\end{tabular}

area was, once again, characterized by high abundance of Rhynchospora britonii (52.7\% of individuals), and the humid grassland by Axonopus affinis (11.5\%).

Principal Coordinates Analysis of the seed bank data from spring (explanation of axes 1 and 2: 54.2\%), showed three well-defined groups. The first axis clearly separated the two grassland areas (on the left) from those with a cultivation history, while the second axis separated both areas with agricultural use (Fig 3). For the seed bank collected in autumn, i.e. with the presence of the transient component of the seed bank, the same separation of grassland and agricultural areas was found along the first ordination axis (explanation: 23.2\%), but the latter were not separated from each other in the scatter diagram.

\section{Similarity between the seed bank and established vegetation}

The number of species found in the established vegetation during the 12 months of floristic research in the four areas totaled 213 . Of these, $36 \%$ were found in the soil seed 

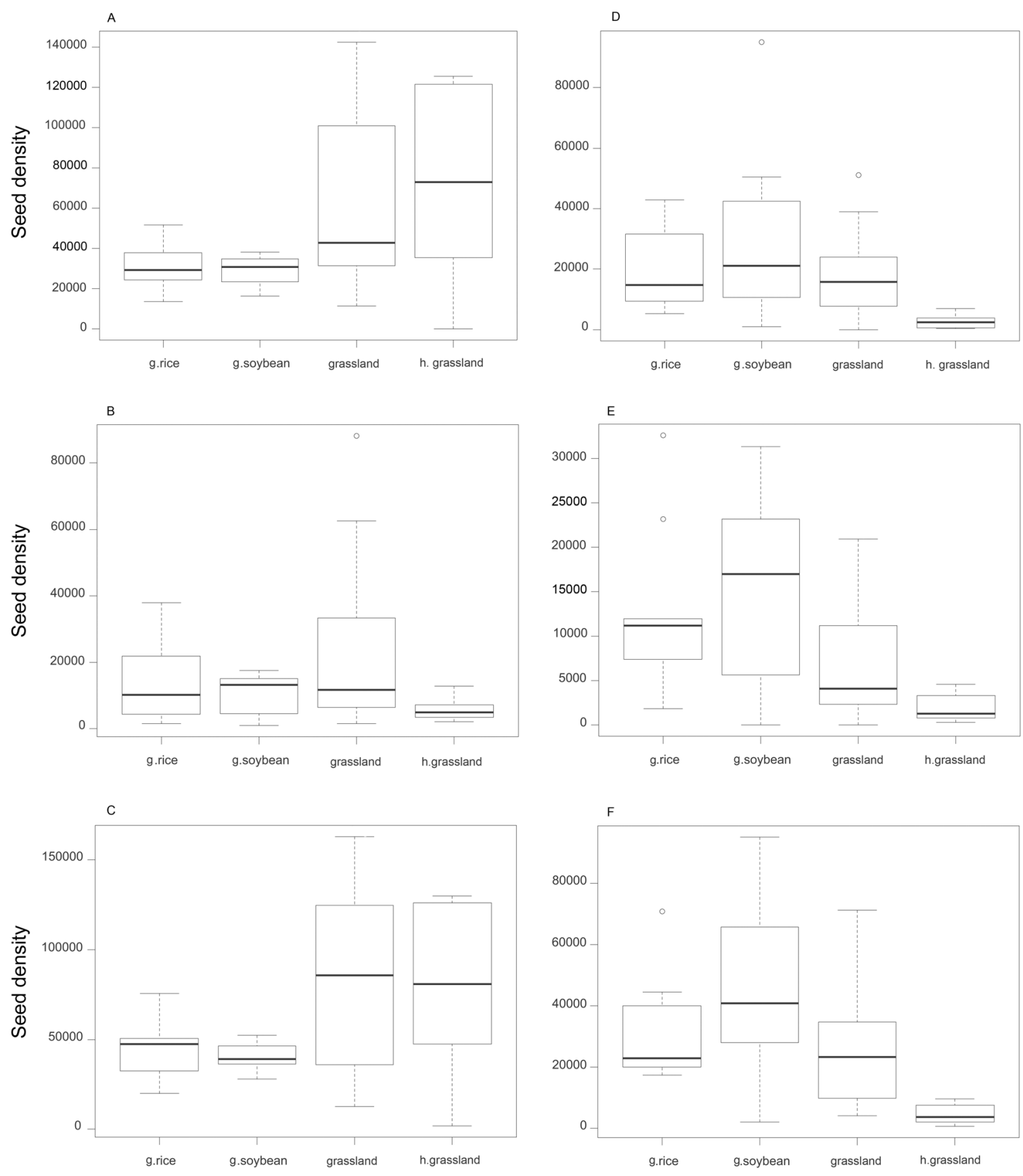

Figure 2. Seed density per $\mathrm{m}^{2}$ in São Lourenço do Sul, RS, Brazil. (A) Upper layer, spring seed bank. (B) Lower layer, spring seed bank. (C) Both layers, spring seed bank. (D) Upper layer, autumn seed bank. (E) Lower layer, autumn seed bank. (F) Both layers, autumn seed bank. Areas: grassland/rice - g.rice; grassland/soybean - g.soybean; grassland and humid grassland - h.grassland.

bank. The seed bank study revealed 32 species that were not found in the aboveground vegetation. $53 \%$ of the total number of species (established vegetation and soil seed bank together) were found exclusively in established vegetation and $13 \%$ exclusively in the soil seed bank. The grassland/ soybean area sowed a very high similarity between soil seed bank and established vegetation. The grassland/rice area and both areas with a history of grazing only had levels of similarity below 0.5 (Tab. 2).
Most of the species found in the established vegetation had a perennial life cycle (exception: grassland/soybean area; Tab. 3), in contrast to the soil seed bank. While grasses were the species group dominating the established vegetation, their contribution to the seed bank was very low. Forb seeds dominated the seed bank in areas with agricultural use, and sedges/rushes the two natural grassland areas (Tab. 3).

In both the grassland/rice and grassland/soybean area, exotic species were present in the established vegetation. 


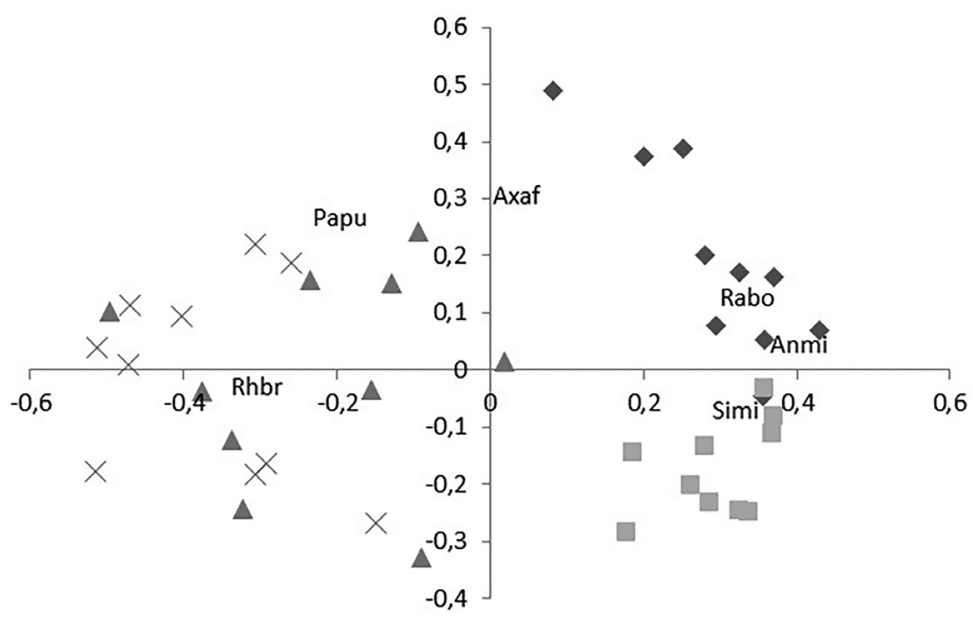

Figure 3. Ordination diagram of seed bank composition of areas under grazing and with past/present agricultural use in São Lourenço do Sul, RS, Brazil. Explanation of the first two ordination axes: $54.2 \%(P=0.4)$ and $11.7 \%(P=0.5)$, respectively. Legend: $\quad$ grassland/rice, $\square$ grassland/soybean, $\Delta$ grassland and $X$ humid grassland, Axaf: Axonopus affinis, Rabo: Ranunculus bonariensis, Anmi: Anagalis minima, Simi: Sisyrinchium micranthum, Rhbr: Rhynchospora brittonii, Papu: Paspalum notatum.

Table 2. Comparison of species composition between established vegetation and seed bank in São Lourenço do Sul, RS, Brazil: Number of exclusive and shared species, Sørensen's index based on quantitative vegetation data for the total seed bank data set.

\begin{tabular}{ccccc}
\hline & $\begin{array}{c}\text { grassland/ } \\
\text { rice }\end{array}$ & $\begin{array}{c}\text { grassland/ } \\
\text { soybean }\end{array}$ & $\begin{array}{c}\text { grazed } \\
\text { grassland }\end{array}$ & $\begin{array}{c}\text { humid } \\
\text { grassland }\end{array}$ \\
\hline $\begin{array}{c}\text { Number of species exclusively in } \\
\text { established vegetation }\end{array}$ & 56 & 121 & 59 & 108 \\
$\begin{array}{c}\text { Number of species exclusively in } \\
\text { soil seed bank (both sampling dates) } \\
\begin{array}{c}\text { Shared species between established } \\
\text { vegetation and soil seed bank }\end{array}\end{array}$ & 35 & 29 & 40 & 19 \\
$\begin{array}{c}\text { Soerensen: Total seed bank vs. } \\
\text { Quantitative vegetation survey }\end{array}$ & 0.460 & 0.840 & 0.433 & 35 \\
\hline
\end{tabular}

The grassland/soybean area had a high proportion of exotic species in terms of abundance, because the period in which the quantitative assessment was conducted, the area was in fallow and seeded with Lolium multiflorum. In both of these areas, exotic species had a considerable contribution to the soil seed bank as well. In the two natural grassland areas, in contrast, the proportion of exotic species in the seed bank was very low (Tab. 3 ).

\section{Discussion}

\section{Seed bank density, richness and composition}

Our study revealed considerable differences in density and composition of the soil seed bank of the two main types of vegetation (grasslands without cultivation and grasslands with historical cultivation). In both sampling seasons, the areas used only for grazing had lower species richness in the soil seed bank when compared to areas with a history of cropping. Species richness was lowest in the humid grassland. This agrees with other studies (Funes et al. 2001; Leck \& Brock 2000; Ungar \& Woodell 1993) and can be explained by the anaerobic conditions during inundation periods, which may influence seed viability and thus acts as an environmental filter that selects species tolerant to these conditions (Bekker et al.1998).

The upper soil layer showed higher seed density at both sampling dates in all areas, as generally observed in seed bank studies. However, in areas with past or present agricultural use, the difference in the vertical distribution of seeds was not as sharp, likely as a consequence of cultivation and associated land management practices. Although the area with a history of rice cropping has not been cropped for six years, the high stocking rate on the site after harvest of rice and the high percentage of bare soil (mean of $30 \%$ per square meter) in combination with high precipitation values likely causes high physical impact on the upper soil layer by trampling by animals, thus allowing for a uniformization of the seed distribution of the first $10 \mathrm{~cm}$ of soil (Ferreira et al. 2010). In areas used only for grazing, the spring seed bank showed a very high dominance of only one species, $R$. britonii.

The lower richness found in the spring seed bank is likely to be a result of the sampling season, which assessed only the permanent fraction of the seed bank. Species richness in the autumn seed bank was higher because the samples taken 
Table 3. Contribution of different biological types, life cycles and origin in established vegetation (plant cover) and the soil seed bank (number of seedlings). Given are mean values for each type of area at the study site in Sao Lourenco do Sul, RS, Brazil.

\begin{tabular}{cccccccc}
\hline \multicolumn{3}{c}{ Established vegetation } & \multicolumn{5}{c}{ Soil seed bank } \\
\hline $\begin{array}{c}\text { g.rice } \\
(\%)\end{array}$ & $\begin{array}{c}\text { g.soybean } \\
(\%)\end{array}$ & $\begin{array}{c}\text { g. grass } \\
(\%)\end{array}$ & $\begin{array}{c}\text { h.grass } \\
(\%)\end{array}$ & $\begin{array}{c}\text { g.rice } \\
(\%)\end{array}$ & $\begin{array}{c}\text { g.soybean } \\
(\%)\end{array}$ & $\begin{array}{c}\text { g. grass } \\
(\%)\end{array}$ & $\begin{array}{c}\text { h.grass } \\
(\%)\end{array}$ \\
\hline 0.14 & 0.06 & 0.94 & 0.33 & 0.33 & 0 & 0.09 & 0 \\
12.91 & 6.77 & 6.15 & 4.74 & 6.67 & 23.12 & 75.96 & 87.06 \\
37.98 & 29.55 & 30.07 & 12.88 & 86.32 & 73.81 & 14.58 & 8.63 \\
48.98 & 63.62 & 62.84 & 82.04 & 6.67 & 3.08 & 9.37 & 4.31 \\
& & & & & & & \\
21.24 & 70.61 & 17.14 & 2.84 & 68.01 & 73.35 & 78.08 & 89.46 \\
78.76 & 29.39 & 82.86 & 97.16 & 31.99 & 26.65 & 21.92 & 10.54 \\
& & & & & & & \\
4.95 & 63.34 & 0.53 & 0.17 & 75.82 & 65.33 & 97.66 & 99.15 \\
95.05 & 36.66 & 99.47 & 99.83 & 24.18 & 34.67 & 2.34 & 0.85 \\
\hline
\end{tabular}

at this time included the transient component of the seed bank, i.e. contained seed that were incorporated into the soil seed bank after seeds were shed in spring and summer (October through to March) but are only viable for a short time. On the other hand, the large proportion of species with low abundances e.g. with up to three seedlings per area (about $20 \%$ of the species found) indicates that species that produce transient seeds in low density may not have been assessed in the sampling (D'Angela et al. 1988).

It is worth pointing out that three of the species found in our seedbank study are found in the Red list of endangered species: Crassula peduncularis and Laurembergia tetrandra, both classified as endangered (EN), and Eryngium divaricatum, classified as vulnerable (VU) according to SEMA RS (2014). Crassula peduncularis actually had high abundances in the seed bank in the areas with cultivation history (see Tab. 1 in supplementary material), indicating that it may be a species dependent frequent disturbances.

\section{Similarity between the seed bank and established vegetation in the natural grassland areas}

The similarity between the soil seed bank and established vegetation was low in the natural grasslands, as a large proportion of species present in the vegetation was absent in the soil seed bank. Low similarity between seed band and vegetation was also observed by Scott \& Morgan (2012) in semi-arid grassland in Australia, but contrasts the general finding of a review on seed banks in different vegetation types (Hopfensperger 2007). A reason for this may be that grassland vegetation in southern Brazil is mostly comprised of grasses and herbs with a perennial life cycle that thus not depend much on seed production for establishment of new individuals for maintenance of their populations.

However it is known that the seedling emergence method, although widely used in studies of soil seed bank may not detect the presence of dormant seeds (Gross 1990; Gonzales \& Ghermandi 2012), for example seeds of Fabaceae or any other group that requires specific factors to overcome dormancy. In our study area, a large part of the species in established vegetation belong to the family Poaceae, Cyperaceae and Asteraceae, and many species of these families may have seeds with physiological dormancy (Baskin \& Baskin 2014) and thus need stimulation to break dormancy. As trays with soil and seeds were exposed to a natural regime of fluctuations in ambient temperature, germination throughout the year should have occurred for many species, especially those where dormancy can be overcome by ripening over time (e.g. Andropogon lateralis, see Eira 1983), but if additional cues were necessary, some species may not have germinated. Dormancy of native grassland species in the region has not achieved much attention in research, with studies available for few species, indicating e.g. hard seed coat dormancy in Paspalum (e.g. Franke \& Nabinger 1996).

For South Brazilian grasslands, it has been shown that many forbs and small shrubs depend on resprouting from underground storage organs after biomass loss, e.g. due to grazing (Fidelis et al. 2014), which may indicate that the seed bank is of little relevance for typical grassland vegetation recovery after this kind of disturbance. This also becomes clear by comparing dominant species in the seed bank and vegetation: Rhynchospora britonii was by far the most abundant species in the seed bank in both grassland areas, 
but represented only a small proportion of the aboveground vegetation. An annual species, $R$. britonii invests much in seed production and probably has a nondeep dormancy, which generated a high number of seedlings germinated throughout the experiment. The high contribution of species from the Cyperaceae to the soil seed bank in this study, especially in the natural grassland areas, corresponds to findings for other grassland ecosystems in the region (Boccanelli \& Lewis 1994; Maia et al. 2003). Annual species in general are poorly represented in aboveground vegetation in grasslands in the Campos Sulinos region, possibly due to lower competitiveness of these species under productive climatic conditions (Overbeck \& Pfadenhauer 2007).

\section{Similarity between the seed bank and established vegetation in the areas with cultivation history}

High similarity between the soil seed bank and established vegetation was found for the area currently under rotation with soybean and grazing, which indicates that recruitment is mostly from the soil seed bank. This high similarity is principally a consequence of the presence of ruderal species, occasioned by constant disturbances due to land management. High similarity between vegetation and the soil seed bank has been observed for disturbed environments elsewhere, such as in areas with cultivation history, or in early stages of succession (Valk \& Davis 1978; Milberg \& Hanson 1993; Amiaud \& Touzard 2004; Scott \& Morgan 2012). Frequent disturbance events generate short cycles between flowering and germination, causing similarity between what is in the seed bank in the soil and vegetation (Chang et al. 2001) and benefitting species with a non-perennial life-cycle, but seeds classified as persistent (e.g. Lunt 1997; López-Marino et al. 2000; Amiaud \& Touzard 2004). In our study, perennials dominated the vegetation in terms of cover at all sites, but contribution of non-perennials was much higher in the site in rotational use with soybean, and also higher at the site with a history of rice cultivation. Exotic species were of higher importance in the soil seed bank in the two areas with cultivation history, principally in the grassland/soybean area, where they also established abundantly in the vegetation, in contrast to the grassland/rice area.

\section{Contribution of seed bank studies of our understanding of vegetation dynamics in subtropical grasslands}

Altogether, our results indicate that the regeneration potential of typical grassland species from the soil seed bank is low in areas that have been subjected to severe disturbance, such as areas with a history of agricultural cultivation. The high density of persistent seed in these areas does indeed seem to contribute to rapid establishment of vegetation cover when more intensive land use is abandoned, but the typical and dominant grassland species, especially the grasses that form the vegetation matrix, are unlikely to be present, as they are absent from or only very scarce in the soil seed bank which is dominated by ruderal species.

Seed limitation of typical native grassland species and presence of annual non-natives in disturbed old-fields areas has been observed in other studies in the southern hemisphere (Tognetti et al. 2010, Standish et al. 2007). Our study, together with the few other available studies of the seed bank of subtropical Campos Sulinos grasslands in Brazil, indicates that the large majority of typical grassland species depend on vegetative regrowth from rhizomes or underground storage organs after a disturbance (Fidelis et al. 2014), or that are short lived in the soil and that regeneration from the seed bank is not the principal plant strategy. As this contrasts the general finding by Hopfensperger (2007; see above), it seems interesting to conduct a comparative analysis of data from temperate grasslands on the one hand and tropical/ subtropical grasslands on the other hand.

However, even if resprouting is the main strategy of vegetation regeneration, small densities of seeds in the soil may indeed be necessary - but also sufficient - to maintain populations at a given site in the long run. We still lack information on population biology of the vast majority of grassland species in the region. Long-term studies on vegetation dynamics that include a detailed analysis of recruitment processes are necessary for a better understanding of the role of the soil seed bank in these systems.

Due to the presence of many species with small amounts of seeds, a large sampling effort is necessary in order to characterize the seed bank of species-rich systems such as the South Brazilian grasslands. Seed bank studies are laboursome, as they require maintenance and control of the samples in the greenhouse for long periods, and complex, as many factors influence the seed bank and any analysis is only a snapshot in time (or two snapshots, in our case) and as all methods have shortcomings (Fourie 2008). Nevertheless, this kind of study contributes to our understanding of vegetation and population dynamics, as illustrated, for example, by the finding of large amounts of seeds of an endangered species absent in the aboveground vegetation. A larger number of seed bank studies seems important to classify species according to plant strategies, as well as to assess recovery potential of degraded vegetation.

\section{Acknowledgments}

We are grateful to Silvia Guimarães de Souza for allowing us to work on her farm and for assistance, to Miguel Dall'Agnol for being able to use the greenhouse at the UFRGS Faculty of Agronomy and to all colleagues who helped with species identification and fieldwork. The comments by two anonymous reviewers helped to improve the manuscript. We thank the Brazilian Coordenação de Aperfeiçoamento de Pessoal de Nível Superior (CAPES) for the Master scholarships to the first and second author. 


\section{References}

Amiaud B, Touzard B. 2004. The relationships between soil seed bank, aboveground vegetation and disturbances in old embanked marshlands of Western France. Flora 199: 25-35.

Bakker HG. 1989. Some Aspects of the Natural History of Seed Banks. In: Leck MA, Parker TV, Simpson RL. (eds.) Ecology of Soil Seed Banks. New York, Academic Press. p. 9-21.

Bakker JP, Poschlod P, Strykstra RJ, Bekker RM, Thompson K. 1996. Seed banks and seed dispersal: important topics in restoration ecology. Acta Botanica Neerlandica 45: 461-490.

Baskin CC, Baskin JM. 2014. Germination ecology of plants with specialized life cicles and/or habitats. In: Baskin CC, Baskin JM. (eds.) SeedsEcology, Biogeography, and Evolution of Dormancy and Germination. San Diego, Academic Press. p. 869-1004.

Bekker RM, Oomes MJM, Bakker JP. 1998. The impact of groundwater level on soil seed bank survival. Seed Science Research 8: 399-404.

Boccanelli SI, Lewis JP. 1994. The seed bank of an old pampean prairie and its relation with the standing vegetation. Pesquisa Agropecuária Brasileira 29: 1833-1840.

Boldrini II. 1997. Campos do Rio Grande do Sul: caracterização fisionômica e problemática ocupacional. Boletim do Instituto de Biociências 56: 1-39.

Boldrini II. 2009. A flora dos campos do Rio Grande do Sul. In: Pillar VDP, Muller SC, Castilhos ZM, Jacques AVA. (eds.) Campos Sulinosconservação e uso sustentável da biodiversidade. Brasília, Ministério do Meio Ambiente. p. 63-67.

Bond WJ, Parr CL. 2010. Beyond the forest edge: Ecology, diversity and conservation of the grassy biomes. Biological Conservation 143: 2395-2404.

Bullock JM, Aronson J, Newton AC, Pywell RF, Rey-Benayas JM. 2011. Restoration of ecosystem services and biodiversity: conflicts and opportunities. Trens in Ecology and Evolution 26: 541-549.

Chang ER, Jefferies RL, Carleton TJ. 2001. Relationship between vegetation and soil seed banks in an artic coastal marsh. Journal of Ecology 89: $367-384$.

Cordeiro JLP, Hasenack H. 2009. Cobertura vegetal atual do Rio Grande do Sul. In: Pillar VDP, Muller SC, Castilhos ZM, Jacques AVA. (eds.) Campos Sulinos- conservação e uso sustentável da biodiversidade. Brasília, Ministério do Meio Ambiente. p. 285-299.

Cramer VA, Hobbs RJ, Standish RJ. 2008. What's new about old-fiels? Land abandonment and ecossystem assembly. Trends in Ecology and Evolution 23: 104-112.

D'Angela E, Facelli JM, Jacobo E. 1988. The role of the permanente soil seed bank in early stages of a post-agricultural succession in the Inland Pampa, Argentina. Vegetatio 74: 39-45.

Eira MTS. 1983: Comparação de métodos de quebra de dormência em sementes de capim Andropogon. Revista Brasileira de Sementes 5: 37-49.

Favreto R, Medeiros RB. 2006. Banco de sementes do solo em área agrícola sob diferentes sistemas de manejo estabelecida sobre campo natural. Revista Brasileira de Sementes 28: 34-44.

Ferreira RRM, Filho JT, Ferreira VM. 2010. Efeitos de sistemas de manejo de pastagem nas propriedades físicas do solo. Semina: Ciências Agrárias 31: 913-932.

Fidelis A. Apezzato BG, Pillar VDP, Pfadenhauer J. 2014.Does disturbance affect bud bank size and bellowground structures diversity in Brazilian subtropical grasslands? Flora- Morphology, Distribution, Functional Ecology of Plants 209: 110-116.

Fourie S.2008. Composition of soil seed bank in alien-invaded grassy fynbos: Potential for recovery after clearing. South African Journal of Botany 74: 445-453.

Franke LB, Nabinger C. 1996. Avaliação da germinação de seis acessos de Paspalum notatum Flügge, nativos de Rio Grande do Sul. Revista Brasileira de Sementes 18: 102-107.

Funes G, Basconcelo S, Díaz S, Cabido M. 2001. Edaphic patchiness influences grassland regeneration from the soil seed-bank in mountain grasslands of central Argentina. Austral Ecology 26: 205-212.

Garcia EN. 2009. O Banco de sementes do solo. In: Pillar VDP, Muller SC, Castilhos ZM, Jacques AVA. (eds.) Campos Sulinos- conservação e uso sustentável da biodiversidade. Brasília, Ministério do Meio Ambiente. p. 78-87.

Gonzalez SL, Ghermandi L. 2012. Comparison of methods to estimate soil seed banks: the role of seed size and mass. Community Ecology 13: $238-242$

Grau RH, Aide M. 2008. Globalization and Land-Use Transitions in Latin America. Ecology and Society 13: 16.

Gross KL. 1990. A comparison of methods for estimating seed numbers in the soil. Journal of Ecology 78: 1079-1093.

Hopfensperger KN. 2007. A review of similarity between seed bank and standing vegetation across ecosystems. Oikos 116: 1438-1448.

Kiehl K, Kirmer A, Donath TW, Rasram L, Hözel N.2010. Species introduction in a restoration projects- Evaluation of different techniques for the establishment of semi-natural grasslands in Central and Northwestern Europe. Basic and Applied Ecology 11: 285-299.

Leck MA, Brock MA. 2000. Ecological and evolutionary trends in wetlands: Evidence from seeds and seed banks in New South Wales, Australia and New Jersey, USA. Plant Species Biology 15: 97-112.

Londo G. 1976. The decimal scale for releves of permanent quadrants. Vegetatio 33: 61-64.

López-Marinõ A, Luiz-Calabuig E, Bermúdez FF. 2000. Floristic composition of established vegetation and soil seed bank in pasture communities under different traditional management regimes. Agriculture Ecosystems and Environment 78: 273-282.

Loydi A, Zalba SM, Distel RA. 2012. Viable seed banks under grazing and exclosure conditions in montane mesic grasslands of Argentina. Acta Oecologica 43: 8-15.

Lunt ID. 1997. Germinable soil seed bank of anthropogenic native grasslands and grassy forest remnants in temperate south-eastern Australia. Plant Ecology 130: 21-34.

Maia FC, Medeiros RB, Pillar VDP, Chollet DMS, Olmedo MOM.2003. Composição, riqueza e padrão de variação do banco de sementes do solo em função da vegetação de um ecossistema de pastagem natural. Iheringia 58: 61-80.

Mattison EHA, Norris K. 2005. Bridging the gaps between agricultural policy, land-use and biodiversity. Trends in Ecology and Evolution 20: 610-616.

Milberg P, Hanson ML. 1993. Soil seed bank and species turnover in a limestone grassland. Journal of Vegetation Science 4: 35-42.

Millennium Ecosystem Assessment. 2005. Ecosystems and human wellbeing: Policy responses. Washington, Island Press.

Nabinger C, Ferreira ET, Freitas AK, Carvalho PCF, San't Anna. DM. 2009. Produção animal com base no campo nativo: aplicações e resultados de pesquisa. In: Pillar VDP, Muller SC, Castilhos ZM, Jacques AVA. (eds.) Campos Sulinos - Conservação e uso sustentável da biodiversidade. Brasília, Ministério do Meio Ambiente. p. 175-198.

Ortega M, Levassor C, Peco B. 1997. Seasonal dynamics of mediterranean pasture seed banks along environmental gradients. Journal of Biogeography 24: 177-195.

Overbeck GE, Muller SC, Fidelis A, et al. 2007. Brazil's neglected biome: The South Brazilian Campos. Perspectives in Plant Ecology, Evolution and Systematics 9: 101-116.

Overbeck GE, Pfadenhauer J. 2007. Adaptive strategies in burned subtropical grassland in southern Brazil. Flora 202: 27-49.

Perrings C, Naeem S, Ahrestani F, et al. 2010. Ecosystem Services for 2020. Science 330: 323-324.

Pillar VD. 2006. MULTIV Software para análise multivariada, testes de aleatorização e autoreamostragem "Bootstrap". v. 2.4.2. Porto Alegre, Universidade Federal do Rio Grande do Sul.

Poiani KA, Johnson WC. 1988. Evaluation of the emergence method in estimating seed bank composition of prairie wetlands. Aquatic Botany 32: 91-97.

Sala OE, Chapin FS, Armesto JJ, et al. 2000. Global Biodiversity Scenarios for the Year 2100. Science 287: 1770-1774.

Scott AJ, Morgan JW. 2012. Resilience, persistence, and relationship to standing vegetation in soil seed bank of semi-arid Australian old fields. Applied Vegetation Science 15: 48-61.

SEMA RS - Secretaria Estadual do Meio Ambiente. 2014. Decreto ${ }^{\circ}$ 52.109, de 1 de dezembro de 2014. Declara as espécies da flora nativa 
ameaçadas de extinção no estado do Rio Grande do Sul. Diário Oficial, Porto Alegre, RS, 02 de dezembro de 2014.

Soriano A, León RJC, Sala OE, et al. 1992. Río de la Plata grasslands. In: Coupland RT. (ed.) Ecosystems of the world. Natural Grasslands. Introduction and Western Hemisphere. Amsterdam, Elsevier. p. 367-407.

Standish RJ, Cramer VA, Wild SL, Hobbs RJ. 2007. Seed dispersal and recruitment limitation are barriers to native recolonization of oldfields in western Australia. Journal of Applied Ecology 44: 435-445.

Streck EV, Kämpf N, Dalmolin RSD, et al. 2008. Solos do Rio Grande do Sul. 2nd. edn. Porto Alegre, Emater.

Thompson K. 2000. The functional ecology of soil seed banks. In: Fenner M. (ed.) Seeds. The Ecology of Regeneration in Plant Communities. 2nd. edn. Wallingford, CABI Publishing. p. 215-236.

Thompson K, Grime JP, 1979. Seasonal variation in the seed banks of herbaceous species in ten contrasting habitats. Journal of Ecology 67: 893-921.
Tognetti PM, Chaneton EJ, Omancini M, Trebino H J, León RJC. 2010. Exotic vs. native plant dominance over 20 years of old-field succession on setaside farmland in Argentina. Biological Conservation 143: 2494-2503.

Ungar IA, Woodel SRJ. 1993. The relationship between the seed bank and species composition of plant communities in two British salt marshes. Journal of Vegetation Science 4: 531-536.

Valk AG, Davis CB. 1978. The role seed bank in the vegetation dynamics of prairie glacial marshes. Ecology 59: 322-335.

Veldman JW, Buisson E, Durigan E, et al. 2015. Toward an old growth concept for grasslands, savanas and woodlands. Frontiers in Ecology and the Environment 13: 154-162.

White R, Murray S, Rohweder M. 2000. Pilot analysis of global ecosystems: Grassland ecosystems technical report. Washington, Word Resources Institute.

Zaloumis NP, Bond WJ. 2011. Grassland restoration after afforestation: No direction home? Austral Ecology 36: 357-366. 